\title{
RISK MANAGEMENT MATURITY, ITS DETERMINANTS AND IMPACT ON FIRM VALUE: EMPIRICAL EVIDENCE FROM JOINT-STOCK COMPANIES IN BOSNIA AND HERZEGOVINA
}

Minela Nuhic Meskovic, Azra Zaimovic

\section{Abstract}

The current extremely volatile business environment requires companies to manage a wide range of risks. Poor management of the company's main risks can lead to significant value losses for key stakeholders. Companies strive to preserve and protect their value by developing risk management models based on organisational culture, processes and structure. The main objective of this paper is to assess the maturity of risk management, explore its determinants and examine its impact on firm value. In order to quantify the maturity of the risk management model, we have created an index based on 31 reference components whose weighting values have been determined by a group of experts using the Delphi technique. In addition, this paper aims to identify the determinants of the risk management model maturity in companies in Bosnia and Herzegovina (B\&H). Based on the estimated ordinary least squares (OLS) model, the results confirm that companies from the financial sector have more mature risk management models compared to the real sector. Moreover, the size of the firm and the type of auditor were identified as additional determinants of risk management maturity. The OLS model confirms the positive and statistically significant impact of risk management model maturity on Tobin's $Q$ value.

Keywords: Enterprise risk management, Tobin's Q, OLS estimator, Delphi technique, questionnaire, B\&H

JEL classification: G32, D81

\section{Introduction}

The current economic environment's complexity, instability, and unpredictability are a daily reminder that companies face many risks. Ignorance, poor assessment and management of the main risks faced by the company can result in significant losses of value for key stakeholders. Under such conditions, risk management models, which are based on the organisational culture of risk management, processes for identification, assessment, treatment, control and monitoring of risks, and organisational structures can help preserve or even increase the value of the company whose
Minela Nuhic Meskovic, PhD candidate

(corresponding author)

Head of Department for plan and analysis

University of Sarajevo

E-mail: minela.nuhic-meskovic@unsa.ba

Address: Obala Kulina bana 7/III, 71000 Sarajevo

ORCID: https://orcid.org/0000-0002-9207-5784

Azra Zaimovic, PhD

Associate Professor

School of Economics and Business

University of Sarajevo

E-mail: azra.zaimovic@efsa.unsa.ba

ORCID: https://orcid.org/0000-0002-3956-4626 
protection is based on the interests of its stakeholders.

Theories offer conflicting explanations regarding the impact of risk management on company value. While the CAPM model developed by Sharpe (1964) does not recognise the value of non-systematic risk management, which is fully diversified according to this theory, and investors demand rewards only for exposure to systematic market risk, the theory of strategic management conceptualised by the CLS model, introduced by Chatterjee et al. (1999) and further elaborated by Lai, Noor, and Fazilah (2011), assumes that a firm's risk management leads to a reduction in costs and required returns, which ultimately translates into an increase in firm value. Some studies (e.g., Chakravarthy 1982; Child 1972; Summer 1980) indicated that organizationally effective non-systematic risk management is a significant cause of organisational evolution, while Bettis (1983) believes that effective non-systematic risk management is the cause that determines which organisations survive and grow and those who sink and die.

Empirical studies dealing with risk management and their impact on the value of companies are also cautious in their findings. Although most empirical findings confirm that risk management has a positive effect on company value, there is insufficient evidence that transmission mechanisms of risk management that affect company values are also applied in markets such as the B\&H, which is often assessed as shallow, inefficient and illiquid (Kumalić 2013; Planinić 2019). In that regard, this paper attempts to answer the following research questions: Is there a relationship between the maturity of risk management models and the company's market values in B\&H? Also, our goal is to examine the determinants of maturity of risk management in B\&H companies, where a model for its assessment was previously created.

Based on the estimated OLS model, it was confirmed that companies from the financial sector have more mature risk management models compared to the real sector. Also, the company's size and the type of auditor were identified as additional determinants of risk management maturity. The results of the study confirmed the positive and statistically significant impact of the risk management maturity model on Tobin's $Q$ value as a widely accepted measure of firm value in similar research.

The paper is structured as follows. After this introductory part, an overview of the literature review is presented, while the third part contains the research methodology, sample selection and model specifications. The fourth part of the paper refers to the research results, while the final part summarises the paper's main findings.

\section{Literature review}

The topic of risk management has been the subject of numerous empirical studies. Global trends in implementing the integrated concept of risk management emphasise researching the maturity of risk management approaches, determining the development of these models, and establishing the relationship between the maturity of risk management models and company performance.

Khalik and Sum (2020) state that measuring the maturity of a risk management model in empirical research is based on the following three ways: (a) using proxy indicators, (b) S\&P ratings, and (c) creating an index. Proxy indicators are used as indirect indicators of risk management model maturity when it is impossible to measure or describe the implementation of risk management models directly. This method has been used in the papers of Hoyt and Liebenberg (2011), Liebenberg and Hoyt (2003), Eckles, Hoyt, and Miller (2014), Tahir and Razali (2011), Beasley, Pagach, and Warr (2008), Pagach and Warr (2011), Agustina and Barororh (2016), Lechner and Gatzert (2018), and for indicators of a more mature form of risk management model in the organisation, proxy indicators were such as the presence of a general risk manager, risk committee, strategic risk management or integrated risk management process. Pooser and McCullough (2012), McShane, Nair, and Rustambekov (2011), Lin, Wen, and Yu (2012), Baxter et al. (2013), Eckles, Hoyt, and Miller (2014) and Bohnert et al. (2019), in their papers, used Standard and Poor's measurement methodology to assess risk management models.

To address the shortcomings and limitations of measuring the maturity of risk management models using the above methods, which are reflected in the dichotomous or qualitative nature of risk management development assessment, some authors developed indices to measure the development of risk management models based on specific components of risk management standards such as ISO and COSO ERM. The use of indices to measure the maturity of risk management can be found in many works (e.g., Desender and Lafuente 2009; Quon, Zeghal, and Maingot 2012; Gordon, Loeb, and Tseng 2009; Jakaša, Osmanagić, and Iliopoulos 2008; Monda and Giorgino 2013; Altuntas, Berry-Stölzle, and Hoyt 2011; Yazid, Hussin, and Daud 2011; Laisasisikorn and Rpmpho 2014; Sprčić, Pećina, and Orsag 2017; Wibowo and Taufik 2017).

In examining the determinants of risk management model maturity, the authors find empirical evidence in several studies that larger firms tend to adopt more mature risk management models (Hoyt 
and Liebenberg 2008, 2011; Beasley, Clune, and Hermanson 2005; Pagach and Warr 2011; Farrell and Gallagher 2015). Some studies suggest that firms in specific industries are more likely to adopt mature risk management models than others due to differences in regulatory requirements and risk awareness within industries (Beasley, Clune, and Hermanson 2005; Golshan and Rasid 2012). For example, the banking and insurance industries are facing significant regulatory pressure for integrative risk management due to solvency regulations through Basel III and Solvency II (Beasley, Clune, and Hermanson 2005; Gatzert and Wesker 2012). Banks and insurance companies are also in the focus of rating agencies. In addition, firms in the financial sector are particularly concerned with presenting an adequate and transparent risk management system in order to increase confidence in capital markets and expand funding sources (Hoyt and Liebenberg 2008).

Several empirical studies show a significant positive relationship between the adoption of a mature risk management model and the choice of the firm's auditor (Beasley, Clune, and Hermanson 2005; Golshan and Rasid 2012) and find that the auditor's affiliation with the Big Four (KPMG, EY, Deloitte, or PricewaterhouseCoopers) increases the likelihood of a more effective risk management system (Golshan and Rasid 2012). Financial structure, especially the leverage, has been empirically shown to be a determinant of the maturity of risk management models, but with significant differences in the results in terms of signs. Thus, while Hoyt and Liebenberg $(2008,2011)$ find a significant negative relationship between leverage and the risk management model maturity, Liebenberg and Hoyt (2003) and Golshan and Rasid (2012) find the opposite, positive relationship between these variables.

The relationship between risk management and market value is examined by Hoyt and Liebenberg (2011), Lechner and Gatzert (2018), Farrell and Gallagher (2015), Florio and Leoni (2017), Callahan and Soielau (2017), Bohnert et al. (2019), who find a significant positive impact of risk management on the value of the sampled companies.

McShane, Nair, and Rustambekov (2011) use five rating categories used by Standard and Poors and confirm a significant positive relationship between risk management and firm value. A positive but not significant effect is found by Tahir and Razali (2011), Li et al. (2014) and Sekerci (2015). In all studies, to approximate shareholder value, Tobin's $Q$ indicator was used as the ratio between the market value of the firm and the sum of the book values of debt and equity, as a measure of generally accepted value that can reflect future expectations. The only exception is the study by Beasley, Branson, and Pagach (2015), who use the cumulative abnormal returns after the announcement of the commitment of CRO. All of these studies were conducted for specific geographic areas or specific industries within those areas.

\section{Research methodology}

The aim of this paper is to fill the gap represented by the insufficient knowledge about the determinants of risk management in B\&H firms and the impact of risk management on firm value. Accordingly, the following hypotheses are tested:

- H1: Firm size, industry sector, leverage ratio, and type of auditor are determinants of more mature risk management models.

- H2: Risk management in B\&H joint-stock companies has a positive impact on firm value..

In order to quantify the maturity level of risk management, a unique index for risk management was created. At the same time, the specific models were based on the OLS method for the cross-section. The index for measuring the maturity of risk management models was created using the following formula:

$$
I_{R M}=\sum_{i=1}^{31} w_{i} \cdot c_{i}
$$

where $w_{i}, i=1,2 \ldots 31$, are the aligned values of the weights of individual components in the model for measuring the maturity of risk management of the expert group, while $c_{i n}$ is the value of the i-th component on the $\mathrm{n}$-th observation. The alignment process is carried out through the implementation of Delphi techniques, while 31 components have been identified by Monda and Giorgino (2013) and include components of organisational risk management culture, processes and organisational structure, whose importance for effective and efficient risk management has also been recognised by Zheng, Yang, and McLean (2010), Lai and Shad (2017), and Lai and Samad (2010). Farrel and Hoon (2009) argue that developing an organisational risk culture is essential and a necessary element of implementation good risk management practices. Risk management processes are, in essence, common to all international risk management frameworks and range from objective setting, risk identification and assessment to risk treating, monitoring and reporting. Lundqvist (2015) appreciates that the conceptual framework of mature risk management differs 
from the traditional concept of risk management for a management structure adapted to risk management processes and reflected in the structure, centralised approach, established responsibilities and formalised processes.

Rowe and Wright (1999) state that the Delphi method, as a process of expert alignment of attitudes, is based on four key elements: 1) anonymity of expert group members, 2) interactive decision making, 3) controlled feedback, and 4) statistical aggregation of responsible groups that enables quantitative analysis and interpretation. Rowe and Wright (1999) also state that for implementing this technique is necessary to ensure a minimum of five experts. For the implementation of Delphi methods, in this research, eight experts in the field of risk management from the territory of $\mathrm{B} \& \mathrm{H}$ were formed, as follows: two representatives of the academic community, one consultant, and five experts from practice. After the members of the expert group had been individually presented the objectives of the research, explained the procedure of conducting the Delphi procedure, they were asked based on theoretical and practical experiences, to validate the identified components and determine their relative importance in the model through the process of adding weights. Although there are no universally accepted rules on the minimum level of consensus to be used, Sumsion (1998) proposes reaching 70 per cent consensus in each round.

The adopted consensus of experts for alignment of the values of individual component weights is achieved by consensus greater or equal to 75 per cent on a single score (at least six identical answers out of eight) as the first criteria. Also, the arithmetic average of weights reaching consensus in a narrow range ( $\pm 10 \%$ of arithmetic mean in range) was used as the second criterion. In order to avoid creating a forced consensus instead of obtaining it spontaneously, the arithmetic mean of the weights, if no consensus is reached based on the previous two criteria by the third iteration, was used after the third iteration. After the implementation of each iteration, experts were provided reports on the conducted iteration, where they had the opportunity to see how other members of the expert group proposed and then to change or maintain their position.

The OLS cross-sectional model was used to specify the first empirical model used to determine the index value determinants and test the first hypothesis. The choice of the model was conditioned by the fact that the dependent variable in the model is continuous, namely the index for measuring the maturity of risk management created through a survey questionnaire that was implemented in 2020. The dependent variable was logarithmic transformed in the initial model. Logarithmic transformation of independent continuous variables was performed to achieve better linearity and model specifications. The model is specificated as follows:

$$
\begin{aligned}
& \ln I_{R M}=a+b_{1} x_{\text {industry }}+b_{2} \ln x_{\text {size }} \\
& +b_{3} \ln x_{\text {leverage }}+b_{4} x_{\text {auditor }}+\text { control variab. }+e
\end{aligned}
$$

where $x_{\text {industry }}$ is industry affiliation variable as dummy variable by assigning code 1 for companies in the financial sector and 0 (zero) for companies in the nonfinancial sector. Companies in the financial sector, due to regulatory requirements, mainly aim to present an adequate and transparent risk management system to increase confidence in capital markets and increase sources of financing (Hoyt and Liebenberg 2008).

$\ln x_{\text {size }}$ - The size of the company, measured by the logarithmic size of the assets, is included in the model because due to global trends, companies face an increasing scope and complexity of risk (Nocco and Stulz 2006). The principle of proportionality states that larger companies face a more greater number of risks, resulting in the need for more sophisticated risk management models (Hoyt and Liebenberg 2011). In addition, larger companies can invest more financial, technological, and human resources to implement appropriate ERM programmes (Beasley, Clune, and Hermanson 2005; Golshan and Rasid 2012).

$\ln x_{\text {leverage }}$ - Financial leverage, as the log-ratio between total liabilities and the book value of capital. The financial structure, especially leverage, was empirically found to be a determinant of the maturity of the risk management model, but with significant differences in the results in terms of signs. Reduction of default risk (Golshan and Rasid 2012) is quite an acceptable and theoretical view that companies with mature risk management models may choose to increase leverage due to improved visibility into risk (Hoyt and Liebenberg 2011). Risk management activities enable companies to reduce debt costs by outlining corporate policies and strategies for risk management (Meulbroek 2002), contributing to more favourable borrowing conditions.

$x_{\text {auditor }}$ - Type of audit as a categorical variable, with two dummy variables, and the first one, in which code 1 (one) is assigned to companies whose last report was audited by the auditor from the Big4 group (Deloitte, PwC, Ernst and Young, KPMG), otherwise code 0 (zero), and another one, in which code 1 (one) is assigned to companies whose last report was audited by some other audit company, otherwise code 0 (zero) is assigned. The reference variable represents 
companies whose report has not been audited. One of the reasons for including this variable in the model was theoretical and empirical evidence that auditors, especially from Big4 groups, are more diligent in auditing companies' annual reports to preserve their reputation (Tolleson and Pai 2011). Dummy variables for geographic diversification and international diversification were used as control variables, as well as continuous variables for profitability and asset opacity, which could further affect the value of the index (Lechner and Gatzert 2018). The expected values of the variables included in the model are shown in Table 1.

An additional OLS cross-section model was specificated to measure the isolated effect of risk management maturity on the firm's value measured by Tobin's Q. Therefore, in this model, as independent variables are included created index as a measure of risk management maturity, its significant determinants from the previous model and additional control variables that could affect the dependent variable, value of Tobin's Q: leverage, profitability and dividend payment, and the following model is specified:

$$
\begin{aligned}
\ln \text { TobinQ }= & a+b_{1} \ln I_{R M}+b_{2} x_{\text {industry }}+b_{3} \ln x_{\text {size }} \\
& +b_{4} x_{\text {audit }}+b_{5} \ln x_{\text {leverage }}+b_{6} \ln x_{R O A} \\
& +b_{7} x_{\text {geogr.divers }}+b_{8} x_{\text {int.divers }} \\
& +b_{9} \ln x_{\text {opacity }}+b_{10} x_{\text {dividend }}+e
\end{aligned}
$$

The inclusion of these control variables was consistent with Lechner and Gatzert (2018), Hoyt and Liebenberg (2003), and Bohnert et al. (2019). The theoretical justification for including the control variable leverage is that the use of financial leverage could increase the value of firms by reducing free cash flow that might otherwise be invested by a manager in suboptimal projects (Jensen 1986). Excessive leverage, on the other hand, can increase bankruptcy. Profitability control in the model was performed due to the fact that profitable companies could trade higher returns on net assets and capital (Allayannis and Weston 2001), achieving higher company value.

Industry diversification can affect company values through economic mechanisms, broader access to capital markets, and risk diversification (Lewellen 1971; Teece 1980). On the other hand, diversification can reduce performance if agency prices increase and lead to inefficient business (Easterbrook 1984; Berger and Ofek 1995). Consequently, the geographical diversification of industry is included as a control variable of Tobin's $Q$ values. The theoretical predictions described for industrial and geographical diversification apply equally to international diversification. As is the case with industrial and geographical diversification, international diversification is related to the costs they have produced from unresolved agency problems and their benefits from economies of scale and risk diversification. Furthermore, while some suggest that international diversification negatively affects Tobin's $\mathrm{Q}$ (Denis and Yost 2002), there is also evidence that the effects of international diversification (Bodnar, Tang, and Weintrop 1997) are positive.

Following a study by Allayannis and Weston (2001) and Lang and Stulz (1994), the indicator variable for dividend payout was included as a control variable. Empirical evidence on the relationship between dividend payout and company values is two-fold. Investors may view the payment of cash in the form of dividends as a sign of exploitation of growth opportunities, which may negatively affect the company's value. In contrast, if dividends reduce free cash flows that could be used for excessive management spending, dividend payments could positively affect value (Hoyt and Liebenberg 2003).

Table 1. Theoretically expected values of included variables in model 1

\begin{tabular}{llc}
\hline Variables & Definition & Theoretically expected value \\
\hline$x_{\text {industry }}$ & Industry affiliation variable & + \\
\hline $\ln x_{\text {Size }}$ & $\begin{array}{l}\text { Size of the company, measured by the logarithmic } \\
\text { size of the assets }\end{array}$ & + \\
\hline $\ln x_{\text {leverage }}$ & $\begin{array}{l}\text { Logarithmic relationship between total liabilities } \\
\text { and the book value of capital. }\end{array}$ & + \\
\hline$x_{\text {auditor }}$ & Type of audit & +
\end{tabular}

Source: Authors' creation 


\subsection{Sample selection and data collection}

The research was conducted with joint-stock companies in B\&H, i.e., companies with evident business continuity, regardless of financial results. From the records of registers of both securities in $\mathrm{B} \& \mathrm{H}$, we have eliminated companies in bankruptcy proceedings, liquidation, change of the organizational, legal form, and those whose banking accounts are blocked. Due to the specifics of financial reporting of investment funds, they are excluded from the research population. The structure of the research population is presented in Table 2.

A questionnaire (available in the Appendix) asking B\&H companies to perform self-assessment on a scale of 1 to 5 for each of the 31 components of the created index was distributed to 579 previously collected email addresses of companies in the total population. We received 141 complete responses, resulting in a response rate of $24.35 \%$. Secondary data for other variables in the specified models were collected from the financial statements of the observed companies for the year 2019. Data were collected through the Bisnode business data service and financial reports that companies submit to the entity stock exchanges.

\section{Results}

\subsection{Index of maturity of risk management}

As already methodologically presented, we have created an index using the Delphi technique, which meant an iterative adjustment of the weight values for individual index components. After implementing the first iteration, the identified components for assessing the maturity of the risk management model were validated, and the weights were aligned for the eight offered components. The second iteration resulted in the alignment of 10 components, while in the third iteration, a consensus was reached on two components. Due to the visible overload of the expert group, the values of the other weights were determined by the arithmetic mean after the third iteration. Interestingly, the academic representatives of the expert group recognised and gave greater importance to the components that were also recognised in previous research as proxy indicators of more mature risk management. The consensus reached at each iteration is shown in Table 3.

In the structure of the index, the expert group ranked the components from the risk management process segment the highest, with a total of 39.62 weights, the organisational culture with 31.43 and then the organisational structure with 28.61. Among the individual components, the components in the organisational structure, the establishment of a separate function for risk management and the appointment of a chief risk officer have the highest values of the aligned weights.

The management commitment component was rated the most critical in the organisational risk culture segment, which is not surprising. Wibowo and Taufik (2017) appreciate that implementing effective risk management processes requires top management's strong and sustainable commitment to these

Table 2. Research population

\begin{tabular}{lccr} 
& $\begin{array}{c}\text { Total number } \\
\text { of stock issuers } \\
\text { in B\&H }\end{array}$ & $\begin{array}{c}\text { Excluded from research population cause: } \\
\text { bankruptcy, liquidation, blocked banking } \\
\text { accounts, and investment funds }\end{array}$ & $\begin{array}{c}\text { Total research } \\
\text { population }\end{array}$ \\
\hline Federation of B\&H & 559 & 321 & 238 \\
\hline Republic Srpska entity & 1,058 & 726 & 332 \\
\hline Brcko District of B\&H & 19 & 10 & 9 \\
\hline Total & 1,636 & 1,057 & 579 \\
\hline
\end{tabular}

Source: Authors' creation

Table 3. Consensus reached on iterations

\begin{tabular}{lcc}
\hline & Number of components & Consensus reached at iterations \\
\hline I iteration & 8 & $25.80 \%$ \\
\hline II iteration & 10 & $58.06 \%$ \\
\hline III iteration & 2 & $64.52 \%$ \\
\hline IV- based on arithmetic mean & 11 & $100.00 \%$ \\
\hline
\end{tabular}

Source: Authors' creation 
processes. Zhao, Hwang and Low (2013) ranked this component as the first item, appreciating that risk management goes precisely "top-down" direction. In the segment of risk management processes, the integration of risks into strategic and business plans got the highest value. Although identified as part of a segment of the risk management process, this component is closely related to the other two components segments.

An overview of the aligned weights of identified components is given in the following table:

Table 4. Values of weights aligned by experts using Delphi technique

\begin{tabular}{|c|c|c|}
\hline \multirow{10}{*}{$\begin{array}{l}\text { Organisational } \\
\text { risk culture } \\
(31.43)\end{array}$} & Board of directors and top management commitment & 4.92 \\
\hline & Common risk language shared within the organisation & 4.92 \\
\hline & Clear defining and communicating of a risk management policy & 4 \\
\hline & Organising learning programs for employees & 3.06 \\
\hline & $\begin{array}{l}\text { Clear communicating of objectives, policies, and risk tolerance thresholds throughout } \\
\text { the entire organisation }\end{array}$ & 3 \\
\hline & Sharing and communicating risk information & 3 \\
\hline & Risk appetite definition and an explicit risk-appetite statement & 2.75 \\
\hline & $\begin{array}{l}\text { Definition of a risk tolerance threshold for each objective of the organisation } \\
\text { considering the risk appetite }\end{array}$ & 2.25 \\
\hline & $\begin{array}{l}\text { Integrating the risk management with the Performance Measurement System (PMS) } \\
\text { particularly with the Balanced Scorecard (BSC) }\end{array}$ & 2.03 \\
\hline & Designing a remuneration and incentive system & 1.5 \\
\hline \multirow{13}{*}{$\begin{array}{l}\text { Risk } \\
\text { management } \\
\text { process } \\
(39.62)\end{array}$} & Integration of RM in the strategic and business plans & 4 \\
\hline & Creation and maintenance of a risk register & 3.759 \\
\hline & Properly using the technology as an aid to support risk management activities & 3.5875 \\
\hline & $\begin{array}{l}\text { Implementation of an efficient and effective process for identifying all relevant potential } \\
\text { risks }\end{array}$ & 3.06 \\
\hline & Using qualitative and quantitative techniques in risk assessment formal process & 3.06 \\
\hline & Development of adequate contingency plans & 3.03 \\
\hline & Periodical repetition of the risk assessment process & 3 \\
\hline & Risk integration in a risk portfolio and evaluation of correlations between them & 3 \\
\hline & $\begin{array}{l}\text { Defining treatment strategy (avoidance, reduction, sharing, retention), considering a } \\
\text { trade-off between costs and benefits, for each risk }\end{array}$ & 3 \\
\hline & Existence of a periodic risk-reporting system & 3 \\
\hline & $\begin{array}{l}\text { Risk classification into risk categories (e.g., strategic, operational, financial, and } \\
\text { compliance, or strategic, operational, financial, and hazards) }\end{array}$ & 2.625 \\
\hline & Prioritisation of risks on a residual basis & 2.5 \\
\hline & $\begin{array}{l}\text { KRI system developing for monitoring risk exposure and ensure it is coherent with KPIs } \\
\text { and firm strategy, inclusive with correction and escalation plans if risks exceed the limits }\end{array}$ & 2 \\
\hline \multirow{8}{*}{$\begin{array}{l}\text { Organisational } \\
\text { structure } \\
(28.61)\end{array}$} & Building a dedicated RM function & 5 \\
\hline & Appointment of a Chief Risk Officer (CRO) & 4.95 \\
\hline & Involving all employees, at all levels, in the risk management process & 3.625 \\
\hline & Independence of the RM function (direct reporting of CRO to the Board or to the CEO) & 3.5 \\
\hline & Integration of the process of RM among all the business functions and unit & 3.05 \\
\hline & Designation of an RM group or team to support CRO's job & 3 \\
\hline & Defining and communicating of roles and responsibilities for the management of risks & 2.7875 \\
\hline & Identifying risk owners responsible for the identification and management of each risk & 2.7 \\
\hline
\end{tabular}

Source: Authors' calculations 
By weighting the presented components, we have created an index based on 31 components. Considering that the values of weights of individual components were determined by aligning of experts' opinions based on the already mentioned criteria and that accordingly the value of some weights was determined on the basis of the arithmetic mean of $75 \%$ of proposed weights, the index ranges from 99.664 (for all answers 1 ) to 498.32 (for all values 5 ), and it is possible to scale it on a scale from 0 to 100 . Descriptive statistics of the index is presented in Table 5.

Table 5. Descriptive statistics of index

\begin{tabular}{lcc} 
& $I_{R M}$ & $I_{R M}(0-100)$ \\
\hline Average & 260.52 & 40.35 \\
St. deviation & 95.031 & 23.83 \\
Max & 469.87 & 92.86 \\
Min & 99.664 & 0 \\
Median & 250.93 & 37.94 \\
\hline
\end{tabular}

Source: Authors' calculations

The average value of the index is 260.52 points or 40.35 points on a scale from 0 (zero) to 100 . The highest value of the index was recorded in the value of 469.87 (92.86) and belonged to companies from the financial sector.
At least $50 \%$ of the analysed companies had an index value less than or equal to 250.93 index points (37.94 on a scale from 0 to 100). The company from the activities of water supply, wastewater disposal and waste management had the lowest value. The distribution of the index is given above.

\subsection{Determinants of the maturity of risk management and the impact of risk management on the value of companies}

Tables 6 and 7 present the elements of descriptive statistics for the variables used in the specified models and the results of the first specified model, respectively.

Determinants of the created index are estimated based on the specified cross-section model. Of the 141 observations for which data were collected, eight were identified as outliers. By keeping the outlier under control, the result meets all the assumptions of the OLS model.

The p-value of the Ramsey reset test of 0.2155 confirmed that the model was correctly specified. Homoscedasticity assumption of random error was satisfied and approved by the p-value of the BreuschPagan homoscedasticity test of 0.3475 . Also, the corresponding $\mathrm{p}$-value of the SK-residual normality test of 0.5633 was higher than the accepted error level, so the residual normality hypothesis was not rejected. The values of the VIFs for all variables were less than 5 ,

Figure 1: Distribution of index

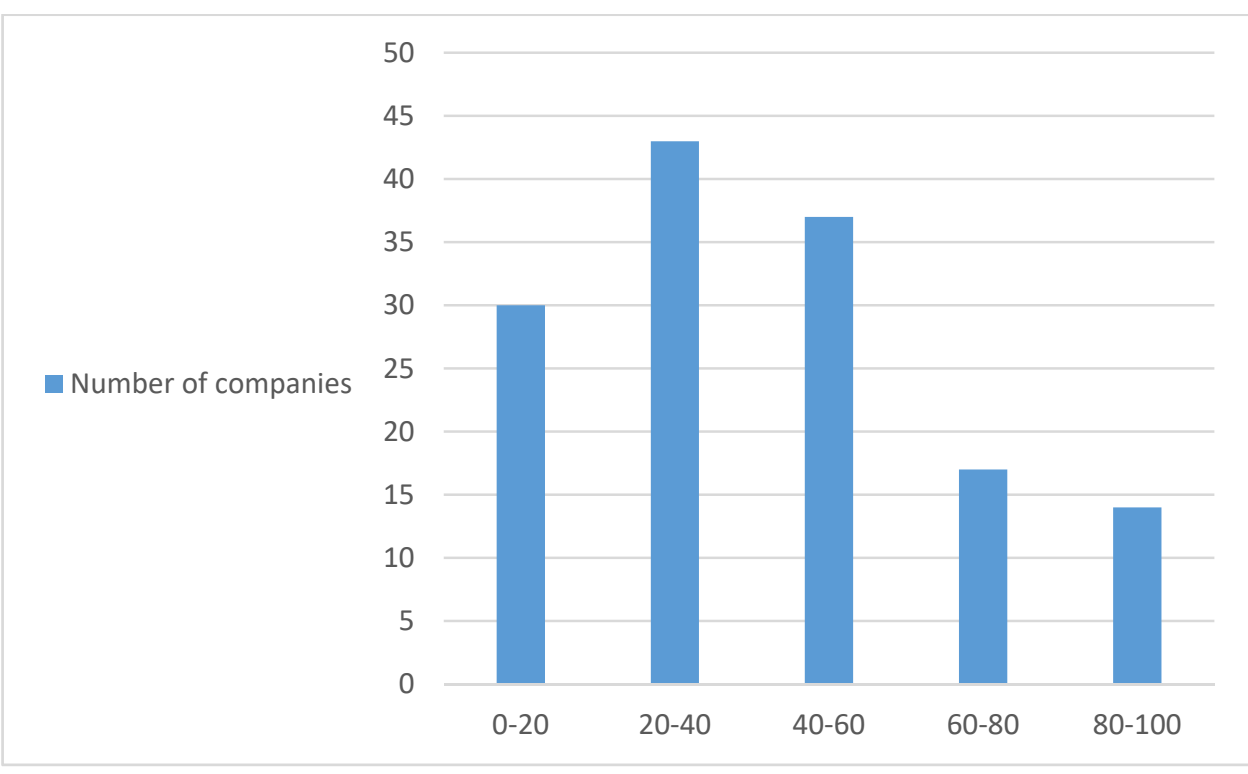

Source: Authors' creation 
Table 6. Descriptive statistics

\begin{tabular}{|c|c|c|c|c|c|c|}
\hline \multicolumn{2}{|c|}{ Variables } & \multirow{2}{*}{$\begin{array}{r}\text { Mean } \\
5.495\end{array}$} & \multirow{2}{*}{$\begin{array}{c}\text { Std.dev. } \\
0.373\end{array}$} & \multirow{2}{*}{$\begin{array}{c}\text { Min. } \\
4.6\end{array}$} & \multirow{2}{*}{$\begin{array}{l}\text { Max. } \\
6.15\end{array}$} & \multirow{2}{*}{$\begin{array}{c}\text { Observations } \\
141\end{array}$} \\
\hline $\ln I_{R M}$ & Index RM & & & & & \\
\hline$x_{\text {industry }}$ & Industry & 0.170 & 0.377 & 0 & 1 & 141 \\
\hline $\ln x_{\text {Size }}$ & Size & 16.144 & 2.178 & 11.76 & 21.95 & 141 \\
\hline $\ln x_{\text {leverage }}$ & Leverage & -1.118 & 1.765 & -5.62 & 2.58 & 141 \\
\hline $\ln x_{R O A}$ & Profitability & 0.016 & 0.073 & -0.24 & 0.42 & 141 \\
\hline$x_{\text {geogr.divers }}$ & $\begin{array}{l}\text { Geographical } \\
\text { diversification }\end{array}$ & 0.355 & 0.480 & 0 & 1 & 141 \\
\hline$x_{\text {int.divers }}$ & $\begin{array}{l}\text { International } \\
\text { diversification }\end{array}$ & 0.603 & 0.491 & 0 & 1 & 141 \\
\hline$x_{\text {auditor_Big4 }}$ & Auditor type - Big4 & 0.163 & 0.371 & 0 & 1 & 141 \\
\hline$x_{\text {auditor_other }}$ & Auditor - others & 0.659 & 0.475 & 0 & 1 & 141 \\
\hline $\ln x_{\text {opacity }}$ & Opacity of assets & 0.013 & 0.043 & 0 & 0.32 & 141 \\
\hline
\end{tabular}

Source: Authors' calculations

Table 7. Estimated parameters of model 1

\begin{tabular}{|c|c|c|c|c|c|c|c|}
\hline $\begin{array}{l}\text { Dependent } \\
\text { variable: }\end{array}$ & Inindex & & & & & & \\
\hline & $\begin{array}{l}\text { Independent } \\
\text { variables }\end{array}$ & Coeff. & Std.dev & $t$ & $\mathrm{P}>|t|$ & {$[95 \%$} & [val] \\
\hline & Constant & 4.455 & 0.179 & 24.81 & $0.000^{*}$ & 4.100 & 4.811 \\
\hline$x_{\text {industry }}$ & Industry & 0.371 & 0.058 & 6.35 & $0.000^{*}$ & 0.255 & 0.486 \\
\hline $\ln x_{\text {Size }}$ & Company size & 0.047 & 0.011 & 4.47 & $0.000^{*}$ & 0.027 & 0.069 \\
\hline $\ln x_{\text {leverage }}$ & Leverage & 0.007 & 0.010 & 0.71 & 0.482 & -0.013 & 0.028 \\
\hline$x_{\text {auditor_Big4 }}$ & Auditor type - Big4 & 0.307 & 0.077 & 3.99 & $0.000^{*}$ & 0.154 & 0.460 \\
\hline$x_{\text {auditor_other }}$ & Auditor - others & 0.272 & 0.050 & 5.38 & $0.000^{*}$ & 0.171 & 0.371 \\
\hline $\ln x_{R O A}$ & Profitability & 0.281 & 0.243 & 1.15 & 0.251 & -0.201 & 0.762 \\
\hline$x_{\text {geogr.divers }}$ & $\begin{array}{l}\text { Geographical } \\
\text { diversification }\end{array}$ & 0.074 & 0.043 & 1.73 & $0.086^{* * *}$ & -0.010 & 0.159 \\
\hline$x_{\text {int.divers }}$ & $\begin{array}{l}\text { International } \\
\text { diversification }\end{array}$ & -0.059 & 0.040 & -1.47 & 0.145 & -0.139 & 0.021 \\
\hline $\ln x_{\text {opacity }}$ & Opacity of assets & 0.695 & 0.493 & 1.41 & 0.161 & -0.281 & 1.672 \\
\hline
\end{tabular}

Source: Authors' calculations

whereby all assumptions were met, and the estimated parameters met the criteria BLUE, the best linear unbiased estimators. The model explains $75.61 \%$ of the total variability of the dependent variable, which is the coefficient of determination of the model.

As the $p$-values for the variables of firm size, sector and type of auditor are less than the error level of $1 \%$, statistical significance was confirmed at all conventional levels of significance for these variables, which leads to the conclusion that with $99 \%$ certainty, we cannot reject the hypothesis that firm size, industry sector and type of auditor are determinants of more matured risk management in B\&H companies.

Table 8 presents the results of the estimated model, the impact of the index on the market value of the company. The model was estimated on 107 observations; how many of 141 companies that have been collected data, are listed on the stock exchange, and Tobin's $Q$ was used as an indicator of market value.

This model also satisfied the Ramsey reset test of the functional form ( $p$-value $=0.5287$ ). Keeping four outliers in the model under control resulted in 
Table 8. Results of the estimated model of measuring the impact of RM on the value of Tobin's Q

\begin{tabular}{|c|c|c|c|c|c|c|c|}
\hline \multicolumn{8}{|c|}{ Dependent variable: $\ln$ Tobin's $Q$} \\
\hline & \multirow{2}{*}{$\begin{array}{l}\text { Independent } \\
\text { variables } \\
\text { Constant }\end{array}$} & \multirow{2}{*}{$\begin{array}{l}\text { Coeff. } \\
-1.194\end{array}$} & \multirow{2}{*}{$\begin{array}{c}\text { Robust } \\
\text { Std.dev. } \\
0.920\end{array}$} & \multirow{2}{*}{$\begin{array}{c}t \\
-1.30\end{array}$} & \multirow{2}{*}{$\begin{array}{r}\mathrm{P}>|t| \\
0.198\end{array}$} & \multicolumn{2}{|c|}{ [95\% interval] } \\
\hline & & & & & & -3.022 & 0.633 \\
\hline $\ln I_{R M}$ & Index & 0.337 & 0.202 & 1.66 & $0.099 * * *$ & -0.065 & 0.739 \\
\hline$x_{\text {sektor }}$ & Industry & 0.027 & 0.169 & 0.16 & 0.872 & -0.308 & 0.362 \\
\hline $\ln x_{\text {size }}$ & Company size & -0.069 & 0.026 & -2.63 & $0.010^{*}$ & -0.121 & -0.017 \\
\hline$X_{\text {auditor_Big4 }}$ & Auditor type - Big4 & 0.210 & 0.264 & 0.79 & 0.429 & -0.315 & 0.735 \\
\hline$X_{\text {auditor_other }}$ & Auditor - others & -0.048 & 0.129 & -0.37 & 0.709 & -0.305 & 0.208 \\
\hline$x_{\text {geogr.divers }}$ & $\begin{array}{l}\text { Geographical } \\
\text { diversification }\end{array}$ & -0.084 & 0.094 & -0.89 & 0.375 & -0.270 & 0.103 \\
\hline $\ln x_{\text {leverage }}$ & Leverage & 0.218 & 0.029 & 7.62 & $0.000^{*}$ & 0.161 & 0.275 \\
\hline $\ln x_{R O A}$ & Profitability & 0.603 & 0.930 & 0.65 & 0.518 & -1.244 & 2.451 \\
\hline$X_{\text {int.divers }}$ & $\begin{array}{l}\text { International } \\
\text { diversification }\end{array}$ & 0.099 & 0.094 & 1.06 & 0.292 & -0.087 & 0.287 \\
\hline $\ln x_{\text {opacity }}$ & Opacity of assets & 0.563 & 1.092 & 0.52 & 0.608 & -1.607 & 2.732 \\
\hline$x_{\text {dividend }}$ & Dividend payments & 0.033 & 0.117 & 0.28 & 0.779 & -0.199 & 0.265 \\
\hline
\end{tabular}

Source: Authors' calculations

satisfying the residual normality assumption, and the $\mathrm{p}$-value of the SK test was 0.5626 . The residual normality assumption cannot be rejected. VIF values also kept values below 5 in this model, and the consequences of disturbing the heteroskedasticity assumption are prevented by using White-Huber standard errors (Gujarati 2003). The coefficient of determination of the model was $61.91 \%$, which explains the variability of the dependent variable.

Based on the estimated model, the index as a measure of the maturity of risk management showed explanatory power in explaining the variability of the dependent variable Tobin's $Q$, at an error level of up to $10 \%$. As the coefficient of the positive sign was estimated with the index variable, and due to the $p$-value of 0.099 , which is less than the error level of 0.10 , we did not reject the hypothesis of a significant positive impact of risk management in explaining the value of companies. Also, next to it, the size variable had a significant but negative sign in the model, which is consistent with the findings of Allayannis and Weston (2011) and Lang and Stulz (1994). The leverage variable showed a significant positive effect on the value of Tobin's Q. Due to the significance of the variable $\ln I_{R M}$, on the value measure Tobin's $Q$, we cannot reject the hypothesis that the process of risk management in joint-stock companies is in the function of creating their value.

\section{Discussion and conclusion}

The creation of an index to measure the maturity of risk management models, validated for this research by a group of experts in these fields, allowed the quantification and ranking of companies in $\mathrm{B} \& \mathrm{H}$ according to the maturity of the risk management model and gives companies the opportunity to selfassess the risk management model. The proposed index includes 31 components identified in the reference literature: Organisational Culture, Organisational Risk Management Processes, and Structure. Compared to the reference study by Monda and Giorgino (2013), eight additional components were added to the index. The inclusion of these components enables a more comprehensive understanding of the risk management approach in B\&H companies.

The results of the study show that the companies in B\&H do not have mature components of an integrated risk management approach. The average value of the created index on the scale from 0 to 100 was 40.35 points, while the highest value of the index was 92.86 points and belonged to a company from the financial sector.

Although the maturity of risk management models is generally low, the study results have revealed that larger companies and those coming from the financial sector have more mature risk management models. The company size as a determinant of the maturity 
of risk management models is also confirmed in the papers of Hoyt and Liebenberg $(2008,2011)$, Pagach and Warr (2011), Farrell and Gallagher (2015) and Lechner and Gatzert (2018). Statistically, significant more matured risk management models in the financial sector result from stricter regulatory requirements regarding risk management, thus guaranteeing a stable financial system, and is in line with the findings of Beasley, Clune, and Hermanson (2005), and Lechner and Gatzert (2018). As a determinant of a more matured risk management approach, the variable of auditor types was also identified. Companies whose last financial report was audited by auditors from the Big4 group or some other audit firm had more matured risk management models compared to companies whose financial statements were not audited in any way. The same findings come from Golshan and Rashid (2012), and Beasley, Clune, and Hermanson (2005), who confirm a significant positive sign in front of the auditor type variable. It affirms that companies whose report was audited by a Big4 auditor have more mature risk management models. In our analysis, leverage was not found as a significant determinant of maturity of risk management, which is consistent with findings come from Lechner and Gatzert (2018), Farrell and Gallagher (2015), and Pagach and Warr (2011).

Despite the fact that the risk management models in joint-stock companies in Bosnia and Herzegovina are still not at the level of best international management practices, the study findings indicated that companies with better risk management models also have higher market values, measured by Tobin's Q. Significance between the maturity of risk management models and market values is confirmed by Hoyt and Liebenberg (2011), Lechner and Gatzert (2018), Farrell and Gallagher (2015), McShane, Nair, and Rustambekov (2011), Florio and Leoni (2017), Callahan and Soielau (2017), and Bohnert et al. (2019). This phenomenon is critical because capital markets in B\&H are often assessed as inefficient, illiquid and complicated. Despite that, they can recognise and valorise risk management through the mechanisms of market prices of capital market instruments. This is especially important for stakeholders, who, according to theories of stakeholders, aim to maximise the value of the company and managers whose efforts to manage risk are recognised and valorised.

The most significant limitation of this research is related to the fact that there is no quality statistical base for researching risk management complex issues in $\mathrm{B} \& \mathrm{H}$. The illiquidity of the capital markets and the ways of forming the market prices of shares that directly affect the considered indicator Tobin's $Q$ could affect the quality of the results obtained in the empirical part of this paper. Despite the likelihood, these limitations may have affected the results of this study, it is assumed that their effects are marginal and that they have not expressively influenced the findings and conclusions of this study.

In methodological terms, further research can be contributed through serious work on expanding, developing and improving the scale for measuring the maturity risk management models. In addition to the identified significant determinants, the existing model can be extended with additional variables to improve its representative measures. The impact of risk management can be observed on some other firm performance, individually or integrated, in addition to Tobin's Q. Various statistical models and methods, such as SEM, logit probit analysis and the like, can certainly be used for this purpose.

\section{References}

Agustina, L., and Baroroh, N. 2016. The relationship between Enterprise Risk Management (ERM) and firm value mediated through the financial performance. Review of Integrative Business and Economics Research, 5(1), 128.

Allayannis, G., and Weston, J. P. 2001. The use of foreign currency derivatives and firm market value. The review of financial studies, 14(1), 243-276.

Altuntas, M., Berry-Stölzle, T. R., and Hoyt, R. E. 2011. Implementation of enterprise risk management: Evidence from the German property-liability insurance industry. The Geneva papers on risk and insurance-issues and practice, 36(3), 414-439.

Baxter, R., Bedard, J. C., Hoitash, R., and Yezegel, A. 2013. Enterprise risk management program quality: Determinants, value relevance, and the financial crisis. Contemporary Accounting Research, 30(4), 1264-1295.

Beasley, M.S., Clune, R., and Hermanson, D. R. 2005. Enterprise risk management: An empirical analysis of factors associated with the extent of implementation. Journal of accounting and public policy, 24(6), 521-531.

Beasley, M., Branson, B., and Pagach, D. 2015. An analysis of the maturity and strategic impact of investments in ERM. Journal of Accounting and Public Policy, 34(3), 219-243.

Beasley, M., Pagach, D., and Warr, R. 2008. Information conveyed in hiring announcements of senior executives overseeing enterprise-wide risk management processes. Journal of Accounting, Auditing \& Finance, 23(3), 311-332.

Berger, P. G., and Ofek, E. 1995. Diversification's effect on firm value. Journal of financial economics, 37(1), 39-65 
Bettis, R. A. 1983. Modern financial theory, corporate strategy and public policy: Three conundrums. Academy of Management Review, 8(3), 406-415.

Bodnar, G., Tang, C., and Weintrop, J. 1997. Both sides of corporate diversification: The value impacts of geographic and industrial diversification.

Bohnert, A., Gatzert, N., Hoyt, R. E., and Lechner, P. 2019. The drivers and value of enterprise risk management: evidence from ERM ratings. The European Journal of Finance, 25(3), 234-255.

Callahan, C., and Soileau, J. 2017. Does enterprise risk management enhance operating performance? Advances in accounting, 37, 122-139.

Chakravarthy, B. S. 1982. Adaptation: A promising metaphor for strategic management. Academy of management review, 7(1), 35-44.

Chatterjee S., et al. 1999. Toward a strategic theory of risk premium: Moving beyond CAPM. Academy of Management Review, 24(3), 556-567.

Child, J. 1972. Organisational structure, environment and performance:The role of strategic choice. sociology, 6(1), $1-22$.

Denis, D. J., Denis, D. K., and Yost, K. 2002. Global diversification, industrial diversification, and firm value. The journal of Finance, 57(5), 1951-1979.

Desender, K., and Lafuente, E. 2009. The influence of board composition, audit fees and ownership concentration on enterprise risk management. Retrieved frompapers. ssrn. com website.

Easterbrook, F. H. 1984. Two agency-cost explanations of dividends. The American economic review, 74(4), 650-659.

Eckles, D. L., Hoyt, R. E., and Miller, S. M. 2014. Reprint of: The impact of enterprise risk management on the marginal cost of reducing risk: Evidence from the insurance industry. Journal of Banking \& Finance, 49, 409-423

Farrel, J. M., and Hoon, A.2009. What's your company Risk Culture. National Association of Corporate Directors Directorship, 50-62.

Farrell, M., and Gallagher, R. 2015. The valuation implications of enterprise risk management maturity. Journal of Risk and Insurance, 82(3), 625-657.

Florio, C., Leoni, G. 2017. Enterprise risk management and firm performance: The Italian case. The British Accounting Review, 49(1), 56-74.

Gatzert, N., and Wesker, H. 2012. A comparative assessment of Basel II/III and Solvency II. The Geneva Papers on Risk and Insurance-Issues and Practice, 37(3), 539-570.

Golshan, N. M., and Rasid, S. A. 2012. Determinants of enterprise risk management adoption: An empirical analysis of Malaysian public listed firms. International Journal of Social and Human Sciences, 6(2012), 119-126.

Gordon, L. A., Loeb, M. P., and Tseng, C. Y. 2009. Enterprise risk management and firm performance: $A$ contingency perspective. Journal of Accounting and Public Policy, 28(4), 301-327.

Gujarati, D. N. 2003. Basic Econometrics fourth edition McGraw-Hill. New York.

Hoyt, R. E., and Liebenberg, A. P. 2008. The value of enterprise risk management: Evidence from the US insurance industry. In unpublished paper, accessed at: http://www. aria. org/meetings/2006papers/Hoyt_Liebenberg ERM_070606.pdf.

Hoyt, R. E., and Liebenberg, A. P. 2011. The value of enterprise risk management. Journal of risk and insurance, 78(4), 795-822.

Jakaša, T., Osmanagić Bedenik, N., Iliopoulos, F. 2008. DETERMINATION OF THE EFFECTIVENESS OF RISK MANAGEMENT SYSTEMS IN THE ELECTRICITY INDUSTRY. Journal of Energy: Energija, 57(2), 156-177.

Jensen, M. C. 1986. Agency costs of free cash flow, corporate finance, and takeovers. The American economic review, 76(2), 323-329.

Khalik, Z. A., and Sum, R. M. 2020. Enterprise Risk Management (ERM) Behaviour Matrix: Mapping ERM Implementations of Non-Financial Public Listed Companies in Malaysia. Journal of Advanced Research in Business and Management Studies, 19(1), 42-59.

Kumalić, I. 2013. Development of the financial market in Bosnia and Herzegovina. EMC REVIEW-ČASOPIS ZA EKONOMIJU, 5(1).

Lai, F. W., and Samad, F. 2010. Enterprise risk management framework and the empirical determinants of its implementation.

Lai, F. W., and Shad, M. K. 2017. Economic Value-Added Analysis for Enterprise Risk Management. Global Business \& Management Research, 9.

Lai, F.W, Noor, A.A and Fazilah, A.S. 2011. A strategic framework for value enhancing enterprise risk management. Journal of global business and economics, 2(1), 23-51.

Laisasikorn, K., and Rompho, N. 2014. A study of the relationship between a successful enterprise risk management system, a performance measurement system and the financial performance of Thai listed companies. The Journal of Applied Business and Economics, 16(2), 81.

Lang, L. H., and Stulz, R. M. 1994. Tobin's q, corporate diversification, and firm performance. Journal of political economy, 102(6), 1248-1280.

Lechner, P., and Gatzert, N. 2018. Determinants and value of enterprise risk management: empirical evidence from Germany. The European Journal of Finance, 24(10), 867-887.

Li, Q., Wu, Y., Marshall, A., Chipulu, M., and Ojiako, U. 2014. Enterprise risk management and firm value within China's insurance industry. Acta Commercii, 14(1), 1-10.

Liebenberg, A. P., and Hoyt, R. E. 2003. The determinants of enterprise risk management: Evidence from the 
appointment of chief risk officers. Risk management and insurance review, 6(1), 37-52.

Lin, Y., Wen, M. M., and Yu, J. 2012. Enterprise risk management: Strategic antecedents, risk integration, and performance. North American Actuarial Journal, 16(1), 1-28.

Lundqvist, S. A. 2015. Why firms implement risk governance-Stepping beyond traditional risk management to enterprise risk management. Journal of Accounting and Public Policy, 34(5), 441-466.

McShane, M. K., Nair, A., and Rustambekov, E. 2011. Does enterprise risk management increase firm value? Journal of Accounting, Auditing \& Finance, 26(4), 641-658.

Meulbroek, L. K. 2002. Integrated risk management for the firm: a senior manager's guide. Available at SSRN 301331.

Monda, B., and Giorgino, M. 2013. An ERM maturity model. In Enterprise Risk Management Symposium. Chicago, IL, IL: Management, Economics and Industrial Engineering Department.

Pagach, D., and Warr, R. 2011. The characteristics of firms that hire chief risk officers. Journal of risk and insurance, 78(1), 185-211.

Planinić, I. 2019. Capital market of Bosnia and Herzegovina a decade after the global financial crisis. Zbornik radova, (XXV), 140-168.

Pooser, D. M., and McCullough, K. A. 2012.ERM Determinants, Use, and Effects on the Firm. American Risk and Insurance Association, Minneapolis, Minnesota.

Quon, T. K., Zeghal, D., and Maingot, M. 2012. Enterprise risk management and firm performance. Procedia-Social and Behavioral Sciences, 62, 263-267.

Rowe, G., and Wright, G. 1999. The Delphi technique as a forecasting tool: issues and analysis. International journal of forecasting, 15(4), 353-375.

Sekerci, N. 2015. Does Enterprise Risk Management create value for firms?: Evidence from nordic countries. Essays on corporate governance, Dissertation, Lund University

Sharpe, W. F. 1964. Capital asset prices: A theory of market equilibrium under conditions of risk. The journal of finance, 19(3), 425-442
Sprcic, D. M., Pecina, E., and Orsag, S. 2017. Enterprise risk management practices in listed croatian companies. UTMS Journal of Economics, 8(3), 219-230.

Summer, C. E. 1980. Strategic behaviour in business and government. Little Brown \& Company

Sumsion, T. 1998. The Delphi technique: an adaptive research tool. British Journal of Occupational Therapy, 61(4), 153-156.

Tahir, I. M., and Razali, A. R. 2011. The Relationship between enterprise risk management (ERM) and firm value: Evidence from Malaysian public listed companies. International journal of economics and management sciences, 1(2), 32-41.

Teece, D. J. 1980. Economies of scope and the scope of the enterprise. Journal of economic behavior \& organisation, 1(3), 223-247.

Tolleson, T. D., and Pai, K. 2011. The big 4 accounting firms: too big to fail. International Journal of Business, Accounting, and Finance, 5(1), 56-66.

Wibowo, A., and Taufik, J. 2017. Developing a self-assessment model of risk management maturity for client organisations of public construction projects: Indonesian context. Procedia engineering, 171, 274-281.

Yazid, A. S., Hussin, M. R., and Daud, W. N. W. 2011. An examination of enterprise risk management (ERM) practices among the government-linked companies (GLCs) in Malaysia. International Business Research, 4(4), 94.

Zhao, X., Hwang, B. G., and Low, S. P. 2013. Developing fuzzy enterprise risk management maturity model for construction firms. Journal of construction engineering and management, 139(9), 1179-1189.

Zheng, W., Yang, B., and McLean, G. N. 2010. Linking organisational culture, structure, strategy, and organisational effectiveness: Mediating role of knowledge management. Journal of Business research, 63(7), 763-771. 


\section{APPENDIX}

\section{Survey questionnaire}

\begin{tabular}{|c|c|c|}
\hline & Components and questions & Choices \\
\hline & Risk culture & \\
\hline 1. & $\begin{array}{l}\text { Component: } \\
\text { Board of directors and top management commitment } \\
\text { Question: } \\
\text { Assess the extent to which management and the board of directors are } \\
\text { involved in the company's risk management process: }\end{array}$ & $\begin{array}{l}\text { Management and the board of directors } \\
\text { are involved in the risk management } \\
\text { process: } \\
5 \text { - in all aspects and phases of manage- } \\
\text { ment of all risks } \\
4 \text { - in all aspects and phases of manage- } \\
\text { ment of the most critical risks } \\
3 \text { - partly for the most critical risks } \\
2 \text { - minimal } \\
1 \text { - not at all }\end{array}$ \\
\hline 2. & $\begin{array}{l}\text { Component: } \\
\text { Common risk language shared within the organisation } \\
\text { Question: } \\
\text { Assess the extent to which the company has implemented some of the } \\
\text { risk management standards (such as ISO } 31001, \text { COSO, FERMA, etc.): }\end{array}$ & $\begin{array}{l}5 \text { - completely } \\
4 \text { - significant } \\
3 \text { - partially } \\
2 \text { - minimal } \\
1 \text { - not at all }\end{array}$ \\
\hline 3. & $\begin{array}{l}\text { Component: } \\
\text { Clear defining and communicating of a RM policy } \\
\text { Question: } \\
\text { Assess the extent to which the company has established risk manage- } \\
\text { ment policies and procedures in the company: }\end{array}$ & $\begin{array}{l}\text { Policies and procedures are: } \\
5 \text { - Fully defined for all risks } \\
\text { 4- Fully defined for the most critical risks } \\
3 \text { - Partially established policies and pro- } \\
\text { cedures for the most critical risks. } \\
2 \text { - There are no policies and procedures, } \\
\text { but they are in preparation. } \\
1 \text {-There are no risk management poli- } \\
\text { cies and procedures. }\end{array}$ \\
\hline 4. & $\begin{array}{l}\text { Component: } \\
\text { Organising learning programs for employees } \\
\text { Question: } \\
\text { Assess the extent to which the company implements professional } \\
\text { development and employee training programs to manage risks more } \\
\text { effectively: }\end{array}$ & $\begin{array}{l}5 \text { - monthly and more often } \\
4 \text { - quarterly } \\
3 \text { - semi-annually } \\
2 \text { - annually } \\
1 \text { - not at all }\end{array}$ \\
\hline 5. & $\begin{array}{l}\text { Component: } \\
\text { Clear communicating of objectives, policies, and risk tolerance thresh- } \\
\text { olds throughout the entire organisation } \\
\text { Question: } \\
\text { Assess the extent to which RM objectives and policies are clearly com- } \\
\text { municated through the company: }\end{array}$ & $\begin{array}{l}5 \text { - completely } \\
4 \text { - significantly } \\
3 \text { - partially } \\
2 \text { - minimal } \\
1 \text { - not at all }\end{array}$ \\
\hline
\end{tabular}




\begin{tabular}{|c|c|c|}
\hline 6. & $\begin{array}{l}\text { Component: } \\
\text { Sharing and communicating risk information } \\
\text { Question: } \\
\text { Assess the stage of the process of implementing the company's } \\
\text { information system }\end{array}$ & $\begin{array}{l}5 \text { - fully implemented for more than } \\
\text { three years } \\
4 \text { - fully implemented up to } 3 \text { years } \\
3 \text { - partially implemented } \\
2 \text { - not implemented, but implementa- } \\
\text { tion is planned in the coming period } \\
1 \text { - not implemented and there is no } \\
\text { implementation plan in the coming } \\
\text { period }\end{array}$ \\
\hline 7. & $\begin{array}{l}\text { Component: } \\
\text { Risk appetite definition and an explicit risk-appetite statement } \\
\text { Question: } \\
\text { Assess the extent to which the company has articulated risk appetites in } \\
\text { the context of strategic planning: }\end{array}$ & $\begin{array}{l}5 \text { - completely } \\
4 \text { - significantly } \\
3 \text { - partially } \\
2 \text { - minimal } \\
1 \text { - not at all }\end{array}$ \\
\hline 8. & $\begin{array}{l}\text { Component: } \\
\text { Definition of a risk tolerance threshold for each objective of the organi- } \\
\text { sation considering the risk appetite } \\
\text { Question: } \\
\text { Assess the extent to which risk tolerance thresholds are aligned with } \\
\text { organisational objectives: }\end{array}$ & $\begin{array}{l}5 \text { - completely } \\
4 \text { - significantly } \\
3 \text { - partially } \\
2 \text { - minimal } \\
1 \text { - not at all }\end{array}$ \\
\hline 9. & $\begin{array}{l}\text { Component: } \\
\text { Integrating RM with the Performance Measurement System (PMS), par- } \\
\text { ticularly with the Balanced Scorecard (BSC) } \\
\text { Question: } \\
\text { Assess the extent to which the company's risk management activities } \\
\text { and policies are integrated into the performance measurement system: }\end{array}$ & $\begin{array}{l}5 \text { - completely } \\
4 \text { - significantly } \\
3 \text { - partially } \\
2 \text { - minimal } \\
1 \text { - not at all }\end{array}$ \\
\hline \multirow[t]{2}{*}{10.} & $\begin{array}{l}\text { Component: } \\
\text { Designing a remuneration and incentive system } \\
\text { Question: } \\
\text { Assess the extent to which internal policies and procedures have } \\
\text { established incentives and rewards for employees for outstanding } \\
\text { performance: }\end{array}$ & $\begin{array}{l}5 \text { - completely } \\
4 \text { - significantly } \\
3 \text { - partially } \\
2 \text { - minimal } \\
1 \text { - not at all }\end{array}$ \\
\hline & Process & \\
\hline 11. & $\begin{array}{l}\text { Component: } \\
\text { Integration of RM in the strategic and business plans } \\
\text { Question: } \\
\text { Assess the extent to which the company's risk management activities } \\
\text { and policies are integrated into strategic and business plans }\end{array}$ & $\begin{array}{l}5 \text { - completely } \\
4 \text { - significantly } \\
3 \text { - partially } \\
2 \text { - minimal } \\
1 \text { - not at all }\end{array}$ \\
\hline 12. & $\begin{array}{l}\text { Component: } \\
\text { Creation and maintenance of a risk register } \\
\text { Question: } \\
\text { Assess the stage of the process of creating and maintaining a risk } \\
\text { register: }\end{array}$ & $\begin{array}{l}5 \text { - The risk register exists and is regu- } \\
\text { larly updated. } \\
4 \text { - The risk register exists and is updated } \\
\text { periodically. } \\
3 \text { - The risk register is being prepared. } \\
2 \text { - There is no risk register, but it is } \\
\text { planned in the coming period. } \\
1 \text { - The risk register does not exist and is } \\
\text { not planned in the coming period. }\end{array}$ \\
\hline
\end{tabular}




\begin{tabular}{|c|c|c|}
\hline 13. & $\begin{array}{l}\text { Component: } \\
\text { Properly using the technology as an aid to support risk management } \\
\text { activities } \\
\text { Question: } \\
\text { Assess the extent to which the implemented information system in the } \\
\text { company ensures the integration of business processes: }\end{array}$ & $\begin{array}{l}5 \text { - completely } \\
4 \text { - significantly } \\
3 \text { - partially } \\
2 \text { - minimal } \\
1 \text { - not at all }\end{array}$ \\
\hline 4. & $\begin{array}{l}\text { Component: } \\
\text { Implementation of an efficient and effective process for identifying all } \\
\text { relevant potential risks } \\
\text { Question: } \\
\text { Assess the extent to which the process of identifying or reviewing po- } \\
\text { tentially significant risks that may affect the achievement of objectives } \\
\text { has been identified: }\end{array}$ & $\begin{array}{l}5 \text { - completely } \\
4 \text { - significantly } \\
3 \text { - partially } \\
2 \text { - minimal } \\
1 \text { - not at all }\end{array}$ \\
\hline 15 & $\begin{array}{l}\text { Component: } \\
\text { Using qualitative and quantitative techniques in risk assessment formal } \\
\text { process } \\
\text { Question: } \\
\text { Which methods does the company primarily use in risk assessment? }\end{array}$ & $\begin{array}{l}5 \text { - quantitative and qualitative methods } \\
4 \text { - quantitative methods } \\
3 \text { - qualitative methods } \\
2 \text { - subjective assessment of the } \\
\quad \text { assessor } \\
1 \text { - none of the above }\end{array}$ \\
\hline 16 & $\begin{array}{l}\text { Component: } \\
\text { Development of adequate contingency plans } \\
\text { Question: } \\
\text { Assess the extent to which the company has provided recovery plans to } \\
\text { ensure the operation of key operations in crisis situations: }\end{array}$ & $\begin{array}{l}5 \text { - completely } \\
4 \text { - significantly } \\
3 \text { - partially } \\
2 \text { - minimal } \\
1 \text { - not at all }\end{array}$ \\
\hline 17. & $\begin{array}{l}\text { Component: } \\
\text { Periodical repetition of the risk assessment process } \\
\text { Question: } \\
\text { Evaluate how often risk assessment is done in your company: }\end{array}$ & $\begin{array}{l}5 \text { - monthly and more often } \\
4 \text { - quarterly } \\
3 \text { - semi-annually } \\
2 \text { - annually } \\
1 \text { - not at all }\end{array}$ \\
\hline 18 & $\begin{array}{l}\text { Component: } \\
\text { Risk integration in a risk portfolio and evaluation of correlations be- } \\
\text { tween them } \\
\text { Question: } \\
\text { Assess the extent to which the integration of risk into the company's risk } \\
\text { portfolio and the assessment of the company's risk linkage are carried } \\
\text { out: }\end{array}$ & $\begin{array}{l}5 \text { - completely } \\
4 \text { - significantly } \\
3 \text { - partially } \\
2 \text { - minimal } \\
1 \text { - not at all }\end{array}$ \\
\hline 19 & $\begin{array}{l}\text { Component: } \\
\text { Defining treatment strategy (avoidance, reduction, sharing, retention), } \\
\text { considering a trade-off between costs and benefits, for each risk } \\
\text { Question: } \\
\text { Assess the extent to which RM strategies are established for identified } \\
\text { risks: }\end{array}$ & $\begin{array}{l}5 \text { - completely } \\
4 \text { - significantly } \\
3 \text { - partially } \\
2 \text { - minimal } \\
1 \text { - not at all }\end{array}$ \\
\hline 20. & $\begin{array}{l}\text { Component: } \\
\text { Existence of a periodic risk-reporting system } \\
\text { Question: } \\
\text { Assess how often the boards are reported on the company's risks: }\end{array}$ & $\begin{array}{l}5 \text { - monthly and more often } \\
4 \text { - quarterly } \\
3 \text { - semi-annually } \\
2 \text { - annually } \\
1 \text { - not at all }\end{array}$ \\
\hline
\end{tabular}




\begin{tabular}{|c|c|c|}
\hline 21. & $\begin{array}{l}\text { Component: } \\
\text { Risk classification into risk categories (e.g., strategic, operational, finan- } \\
\text { cial, and compliance, or strategic, operational, financial, and hazards) } \\
\text { Question: } \\
\text { Assess the extent to which risk classification is carried out for the pur- } \\
\text { poses of RM according to established criteria (strategic, operational, } \\
\text { financial, compliance, etc.): }\end{array}$ & $\begin{array}{l}5 \text { - completely } \\
4 \text { - significant } \\
3 \text { - partially } \\
2 \text { - minimal } \\
1 \text { - not at all }\end{array}$ \\
\hline 22. & $\begin{array}{l}\text { Component: } \\
\text { Prioritisation of risks on a residual basis } \\
\text { Question: } \\
\text { Assess the extent to which risk prioritisation is implemented in the } \\
\text { company: }\end{array}$ & $\begin{array}{l}5 \text { - completely } \\
4 \text { - significant } \\
3 \text { - partially } \\
2 \text { - minimal } \\
1 \text { - not at all }\end{array}$ \\
\hline \multirow[t]{2}{*}{23.} & $\begin{array}{l}\text { Component: } \\
\text { KRI system developing for monitoring risk exposure and ensure it is co- } \\
\text { herent with KPIs and firm strategy, inclusive with correction and escala- } \\
\text { tion plans if risks exceed the limits } \\
\text { Question: } \\
\text { Assess the extent to which recovery plans for providing key operations } \\
\text { in crisis situations have been tested in the company: }\end{array}$ & $\begin{array}{l}5 \text { - completely } \\
4 \text { - significant } \\
3 \text { - partially } \\
2 \text { - minimal } \\
1 \text { - not at all }\end{array}$ \\
\hline & Organisational structure & \\
\hline 24. & $\begin{array}{l}\text { Component: } \\
\text { Building a dedicated RM function } \\
\text { Question: } \\
\text { Assess at what stage is the establishment and construction of a dedi- } \\
\text { cated function / department in charge of risk management }\end{array}$ & $\begin{array}{l}5 \text { - systematised and established func- } \\
\text { tion/department for more than three } \\
\text { years } \\
4 \text { - systematised and established func- } \\
\text { tion/department for more than one } \\
\text { year } \\
3 \text { - systematised and established func- } \\
\text { tion/department shorter than one } \\
\text { year } \\
2 \text { - systematized or non-established } \\
\text { function } \\
1 \text { - a separate function/department is } \\
\text { not systematised or established }\end{array}$ \\
\hline 25. & $\begin{array}{l}\text { Component: } \\
\text { Appointment of a CRO } \\
\text { Question: } \\
\text { Assess the stage of the process of appointing the CRO: }\end{array}$ & $\begin{array}{l}5 \text { - appointed general risk manager } \\
\text { more than three years ago } \\
4 \text { - appointed general risk manager } \\
\text { more than one year ago } \\
3 \text { - appointed general risk manager less } \\
\text { than one year ago } \\
2 \text { - the general risk manager is in the } \\
\text { process of selection } \\
1 \text { - no general risk manager has been } \\
\text { appointed }\end{array}$ \\
\hline 26. & $\begin{array}{l}\text { Component: } \\
\text { Involving all employees, at all levels, in RM process } \\
\text { Question: } \\
\text { Asess the extent to which all employees at all levels are involved in the } \\
\text { RM process: }\end{array}$ & $\begin{array}{l}5 \text { - completely } \\
4 \text { - significant } \\
3 \text { - partially } \\
2 \text { - minimal } \\
1 \text { - not at all }\end{array}$ \\
\hline
\end{tabular}




\begin{tabular}{|c|c|c|}
\hline 27. & $\begin{array}{l}\text { Component: } \\
\text { Independence of RM function (direct reporting of CRO to board or to } \\
\text { CEO) } \\
\text { Question: } \\
\text { Assess the extent to which the independence and objectivity of the risk } \\
\text { management function/department is ensured: }\end{array}$ & $\begin{array}{l}5 \text { - completely } \\
4 \text { - significant } \\
3 \text { - partially } \\
2 \text { - minimal } \\
1 \text { - not at all }\end{array}$ \\
\hline 28. & $\begin{array}{l}\text { Component: } \\
\text { Integration of the process of RM among all the business functions and } \\
\text { unit } \\
\text { Question: } \\
\text { Assess the extent to which all business processes in the company have } \\
\text { been identified and documented: }\end{array}$ & $\begin{array}{l}5 \text { - completely } \\
4 \text { - significant } \\
3 \text { - partially } \\
2 \text { - minimal } \\
1 \text { - not at all }\end{array}$ \\
\hline 29. & $\begin{array}{l}\text { Component: } \\
\text { Designation of a RM group or team to support CRO's job } \\
\text { Question: } \\
\text { Assess the stage of appointing interdisciplinary risk management teams } \\
\text { that provide functional support in the work of the chief risk manager } \\
\text { and an understanding of all the company's risks }\end{array}$ & $\begin{array}{l}5 \text { - appointed interdisciplinary teams } \\
\text { more than three years ago } \\
4 \text { - appointed interdisciplinary team } \\
\text { more than one year ago } \\
3 \text { - appointed interdisciplinary team less } \\
\text { than one year ago } \\
2 \text { - an interdisciplinary team to support } \\
\text { the work of the chief risk manager is } \\
\text { in the selection process } \\
1 \text { - there are no separate teams to assist } \\
\text { the work of the chief risk manager }\end{array}$ \\
\hline 30. & $\begin{array}{l}\text { Component: } \\
\text { Defining and communicating of roles and responsibilities for the man- } \\
\text { agement of risks } \\
\text { Question: } \\
\text { Assess the extent to which the roles and responsibilities of all those } \\
\text { involved in the risk management process have been identified }\end{array}$ & $\begin{array}{l}5 \text { - completely } \\
4 \text { - significant } \\
3 \text { - partially } \\
2 \text { - minimal } \\
1 \text { - not at all }\end{array}$ \\
\hline 31. & $\begin{array}{l}\text { Component: } \\
\text { Identifying risk owners responsible for the identification and manage- } \\
\text { ment of each risk } \\
\text { Question: } \\
\text { Indicate which of the following functions/departments is responsible for } \\
\text { identifying and managing risks: }\end{array}$ & $\begin{array}{l}5 \text { - designated process owners } \\
4 \text { - RM department } \\
3 \text { - internal audit department } \\
2 \text { - finance/accounting department } \\
1 \text { - no one in the company identifies the } \\
\quad \text { risk }\end{array}$ \\
\hline
\end{tabular}

